\title{
Tidal Current Energy Resource Assessment in Ireland: Current Status and Future Update
}

\author{
Fergal O'Rourke \\ Technological University Dublin, fergal.orourke@tudublin.ie \\ Fergal Boyle \\ Technological University Dublin, fergal.boyle@tudublin.ie \\ Anthony Reynolds \\ Technological University Dublin, anthony.reynolds@tudublin.ie
}

Follow this and additional works at: https://arrow.tudublin.ie/engschmecart

Part of the Mechanical Engineering Commons

\section{Recommended Citation}

O'Rourke, F., Boyle, F., Reynolds, A.: Tidal current energy resource assessment in Ireland: Current status and future update. Renewable and Sustainable Energy Reviews, 2010. 14(9): p. 3206-3212. doi:10.1016/ j.rser.2010.07.039

This Article is brought to you for free and open access by the School of Mechanical and Design Engineering at ARROW@TU Dublin. It has been accepted for inclusion in Articles by an authorized administrator of ARROW@TU Dublin. For more information, please contact arrow.admin@tudublin.ie, aisling.coyne@tudublin.ie, gerard.connolly@tudublin.ie.

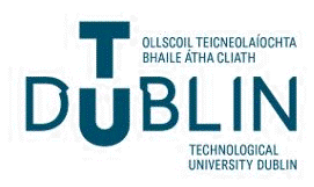


Antenna \& High Frequency Research Centre

\title{
Articles
}

Dublin Institute of Technology

Year 2010

\section{Tidal Current Energy Resource Assessment in Ireland: Current Status and Future Update}

\author{
Fergal O'Rourke* $\quad$ Fergal Boyle $^{\dagger}$
}

Anthony Reynolds $\ddagger$

*Dublin Institute of Technology, fergal.orourke@dit.ie

${ }^{\dagger}$ Dublin Institute of Technology

${ }^{\ddagger}$ Dublin Institute of Technology

This paper is posted at ARROW@DIT.

http://arrow.dit.ie/ahfrcart/12 


\section{— Use Licence}

\section{Attribution-NonCommercial-ShareAlike 1.0}

You are free:

- to copy, distribute, display, and perform the work

- to make derivative works

Under the following conditions:

- Attribution.

You must give the original author credit.

- Non-Commercial.

You may not use this work for commercial purposes.

- Share Alike.

If you alter, transform, or build upon this work, you may distribute the resulting work only under a license identical to this one.

For any reuse or distribution, you must make clear to others the license terms of this work. Any of these conditions can be waived if you get permission from the author.

Your fair use and other rights are in no way affected by the above.

This work is licensed under the Creative Commons Attribution-NonCommercialShareAlike License. To view a copy of this license, visit:

- URL (human-readable summary):

http://creativecommons.org/licenses/by-nc-sa/1.0/

- URL (legal code):

http://creativecommons.org/worldwide/uk/translated-license 


\title{
Tidal Current Energy Resource Assessment in Ireland: Current Status and Future Update
}

\author{
Fergal O'Rourke*, Fergal Boyle, Anthony Reynolds \\ Department of Mechanical Engineering, \\ Dublin Institute of Technology, Bolton Street, Dublin 1, Ireland
}

\begin{abstract}
Interest in renewable energy in Ireland has increased continually over the past decade. This interest is due primarily to security of supply issues and the effects of climate change. Ireland imports over $90 \%$ of its primary energy consumption, mostly in the form of fossil fuels. The exploitation of Ireland's vast indigenous renewable energy resources is required in order to reduce this over dependence on fossil fuel imports to meet energy demand. Various targets have been set by the Irish government to incorporate renewable energy technologies into Ireland's energy market. As a result of these targets, the development in wind energy has increased substantially over the past decade; however this method of energy extraction is intermittent and unpredictable. Ireland has an excellent tidal current energy resource and the use of this resource will assist in the development of a sustainable energy future. Energy extraction using tidal current energy technologies offers a vast and predictable energy resource. This paper reviews the currently-accepted tidal current energy resource assessment for Ireland. This assessment was compiled by Sustainable Energy Ireland in a report in 2004. The assessment employed a 2-dimensional numerical model of the tidal current velocities around Ireland, and from this numerical model the theoretical tidal current energy resource was identified. With the introduction of constraints and limitations, the technical, practical, accessible and viable tidal current energy resources were obtained. The paper discusses why the assessment needs updating including the effect on the assessment of the current stage of development of tidal current turbines and their deployment technology.
\end{abstract}

Keywords: Tidal current, tidal resource assessment, Ireland

\section{Contents}

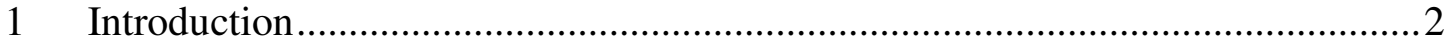

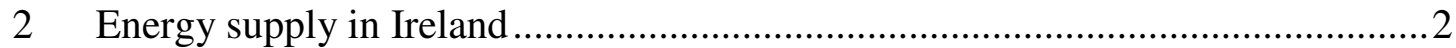

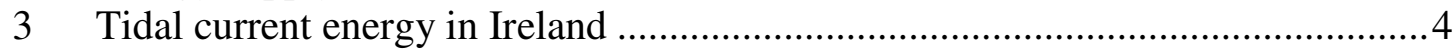

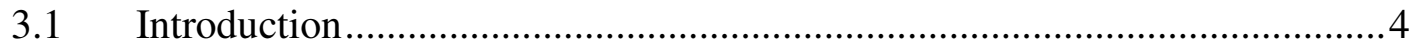

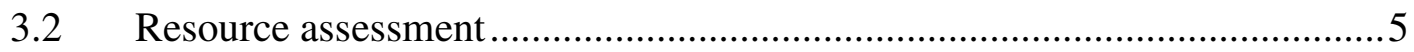

3.2.1 Theoretical tidal current energy resource ............................................. 5

3.2.2 Technical tidal current energy resource ........................................... 7

3.2.3 Practical tidal current energy resource.............................................. 7

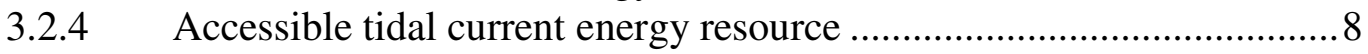

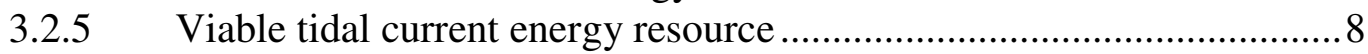

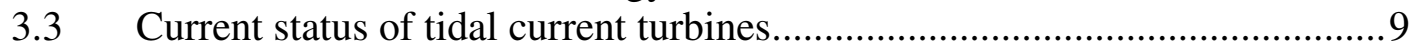

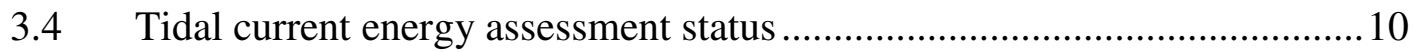

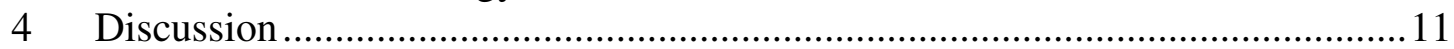

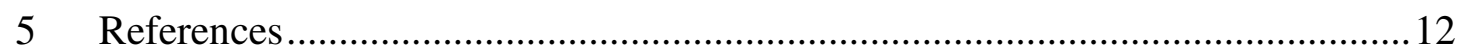

* Corresponding author: Tel.:+353 14022978

E-mail address: fergal.orourke@dit.ie 


\section{Introduction}

Security of supply and climate change issues arising from an over-dependence on fossil fuels to meet energy demand have led to an increase in the use of renewable energy technologies[1]. Access to energy sources is essential for economic development. The stability of prices, geographic distribution, remaining reserves, etc, have led to substantial vulnerabilities, such as political instability of fossil fuel producing countries. Currently, climate change is at the pinnacle of international political agenda. The ratification of the Kyoto Protocol set out a target for each ratified country to reduce their $\mathrm{CO}_{2}$ emissions to 1990 levels [2]. This has resulted in an increase in the development and installation of renewable energy technologies[3].

Ireland's energy supply is predominately made up of the combustion of fossil fuel for electricity generation, heat generation and transportation. This over-use of fossil fuels has resulted in Ireland becoming heavily dependant on energy imports[4]. The utilisation of renewable energy technologies has the potential to alleviate the issues relating to the over-reliance on conventional fuel supplies as they are indigenous and non-polluting [5-7]. Ireland has increased the amount of electricity generated from wind energy; however the main disadvantage of most renewable energy technologies are their intermittent availability and variation in energy intensity [8]. Tidal current energy has an advantage over other renewable energy sources as it is predictable over long time scales [9].

Ireland has an excellent tidal energy resource that has yet to be exploited on a commercial scale. Several tidal current energy sites around Ireland have been identified as having an excellent tidal current energy resource. The currently-accepted, theoretical, tidal current energy resource was identified based on a 2-dimensional (2D) numerical model. The technical, practical and accessible limitations were applied to the theoretical resource assessment [10]. The viable tidal current energy resource was then calculated based on an economic model.

This paper presents the current status of tidal current energy in Ireland. The currently accepted tidal current energy resource assessment is discussed with regards to the development in tidal current turbines and their deployment technology. The paper also addresses the fact that tidal current energy extraction is a viable option for Ireland and with further marine spatial planning, effective policies and technology development, the identified viable tidal current energy resource may increase substantially.

\section{Energy supply in Ireland}

Ireland is heavily dependant of fossil fuel imports to meet energy demand. In 2006 energy consumption in Ireland reached 13.011 million tons of oil equivalent (mtoe) with the use of fossil fuels, primarily oil and natural gas, accounting for $96 \%$ of the energy consumed as shown in Figure 1. Ireland's only indigenous fossil fuel resource is peat; all other fossil fuels are imported making Ireland the most import dependant country in the EU [11]. Ireland's energy is consumed by electricity generation, heat generation and transportation which in 2006 accounted for $32 \%, 26.5 \%$ and $41.5 \%$ of the total final energy consumption respectively [12]. In 2006 renewable energy accounted for $8.6 \%$ of Ireland's electricity consumption [13].

Ireland's energy demand has increased significantly over the period 1990-2006. This has resulted in a considerable increase in the use of fossil fuels. Figure 1 illustrates the final energy consumption of each of the main fuels used over this period. The use of natural gas increased at an average annual rate of $4.3 \%$ as a result of its increased use in the residential and industrial sectors, and as a replacement for other fuels to 
generate electricity. Two combined cycle gas turbines were installed to generate electricity, the first of these coming on stream in August 2002 with a power capacity of 392 MW and the second in November 2002 with a power capacity of 343 MW. The use of oil has also increased significantly since 1990 with a growth of $111 \%$ over this period. The use of renewable energy increased by $57.4 \%$ over this period also. This increase in the use of renewable energy was achieved by the installation of wind turbines to generate electricity. However the renewable energy share percentage of the total final energy consumption has decreased from $1.5 \%$ in 1990 to $1.4 \%$ in 2006.

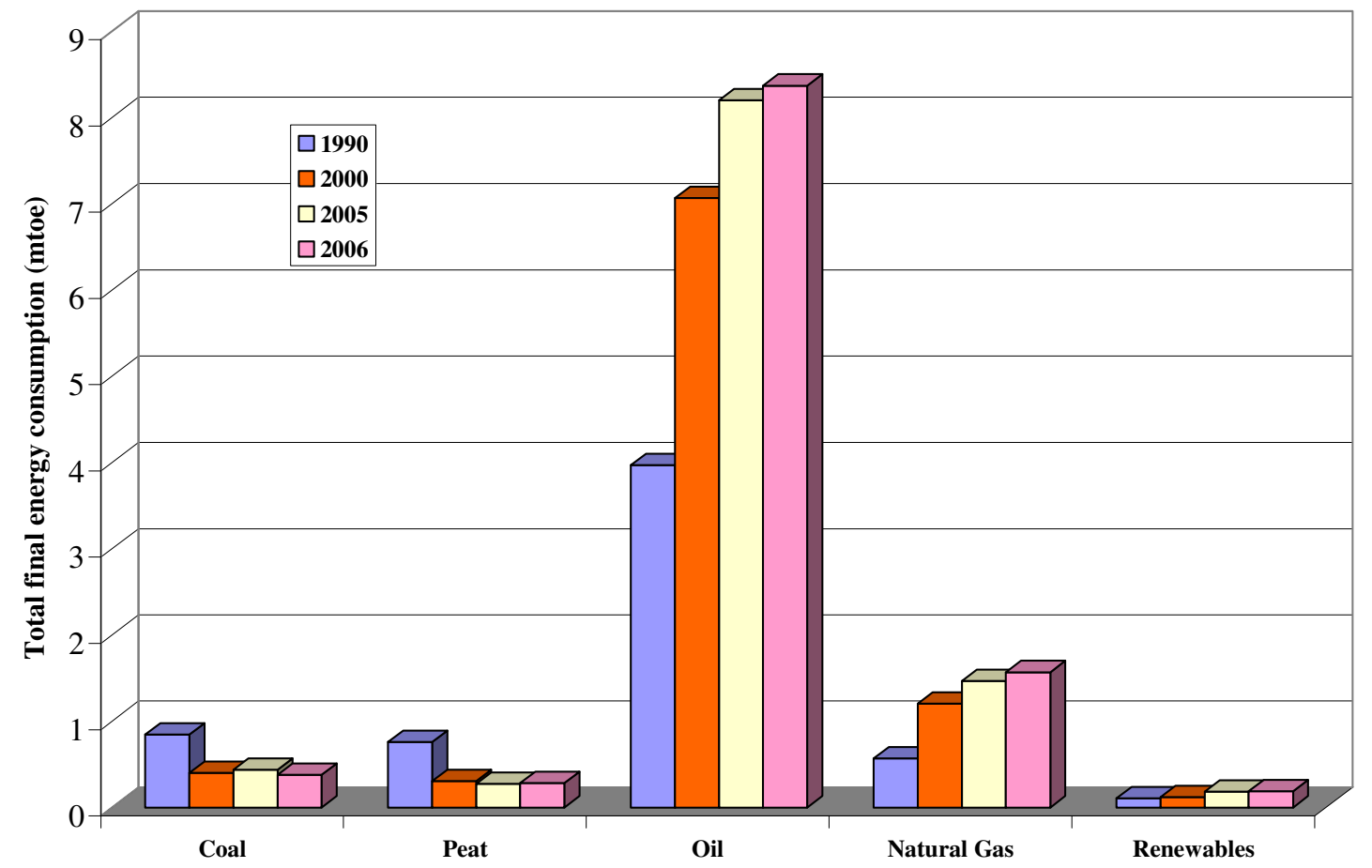

Figure 1. The total final energy consumption by fuel in Ireland from 1990 to 2006 [11]

This over-dependence on fossil fuel imports to meet energy demand has resulted in political decisions to diversify energy supply. An Irish government white paper entitled Delivering a Sustainable Energy Future for Ireland was published by the Department of Communications, Marine and Natural Resources on March $12^{\text {th }} 2007$. This white paper sets out actions towards 2020 to ensure a secure energy supply, to promote sustainable energy supply and use, and to enhance the cost and competitiveness of energy supply [14]. With regard to renewable energy technologies the following targets were set:

- $15 \%$ of Ireland's electricity consumption will be generated from renewable energy technologies by 2010 and $33 \%$ from renewable energy technologies by 2020 . This was increased to $40 \%$ from renewable energy technologies by 2020 on November $13^{\text {th }} 2008$.

- $500 \mathrm{MW}$ installed capacity of ocean energy, and $800 \mathrm{MW}$ of combined heat and power (CHP) with an emphasis on biomass will be installed by 2020 .

- $30 \%$ biomass co-fired at the state-owned peat-powered power plants by 2015 .

Prior to the publication of the white paper, an ocean energy strategy for Ireland was published by Department of Communications, Marine and Natural Resources in October 2005, in a paper entitled Ocean Energy in Ireland [10]. The paper outlines a 
strategy to promote the development of ocean energy technologies and is structured in four phases:

1. Development 2005-2007 - this phase sets out the goal to support developers of ocean energy devices through concept validation, model optimisation and scale model testing.

2. Pre-Commercial Single Devices 2008-2010 - this phase sets out the goal to provide support for a pre-commercial, grid-connected, full-scale, single ocean energy device.

3. Pre-Commercial 10 MW Array Demonstration 2011-2015 - this phase sets out the goal to provide support for the development of a $10 \mathrm{MW}$ commercial gridconnected array of ocean energy devices.

4. 2016 Onwards - this phase sets out the goal to facilitate the integration of largescale ocean energy to the national grid.

\section{Tidal current energy in Ireland}

\subsection{Introduction}

Ireland is an island nation with a coastline roughly $7500 \mathrm{~km}$ in length that comes into contact with several oceans [15]. Most of the tidal-current-flow research along the coastline to-date was done for the purpose of mapping fish species and spawning areas, and for the benefit of shipping. Relatively little work has been published in the interest of tidal current energy resource assessments. Strong tidal currents are common along the north and east coast. The tidal current flow is particularly energetic entering the Irish Sea from the St. Georges Channel and the North Channel (see Figure 2). Tidal current flows are relatively low along the west and south coasts. The bathymetry and hydrography of Ireland's coastline influences the local tidal currents. The large tidal currents are commonly located between land masses or adjacent to headlands [16]. These narrow straits cause a funnelling effect, increasing the velocity of the tidal current flow $[17,18]$. The velocity of the tidal current is the major factor when assessing the tidal current energy resource $[19,20]$. In the following sections, the currently adopted tidal current energy resource assessment for Ireland is discussed in detail. 


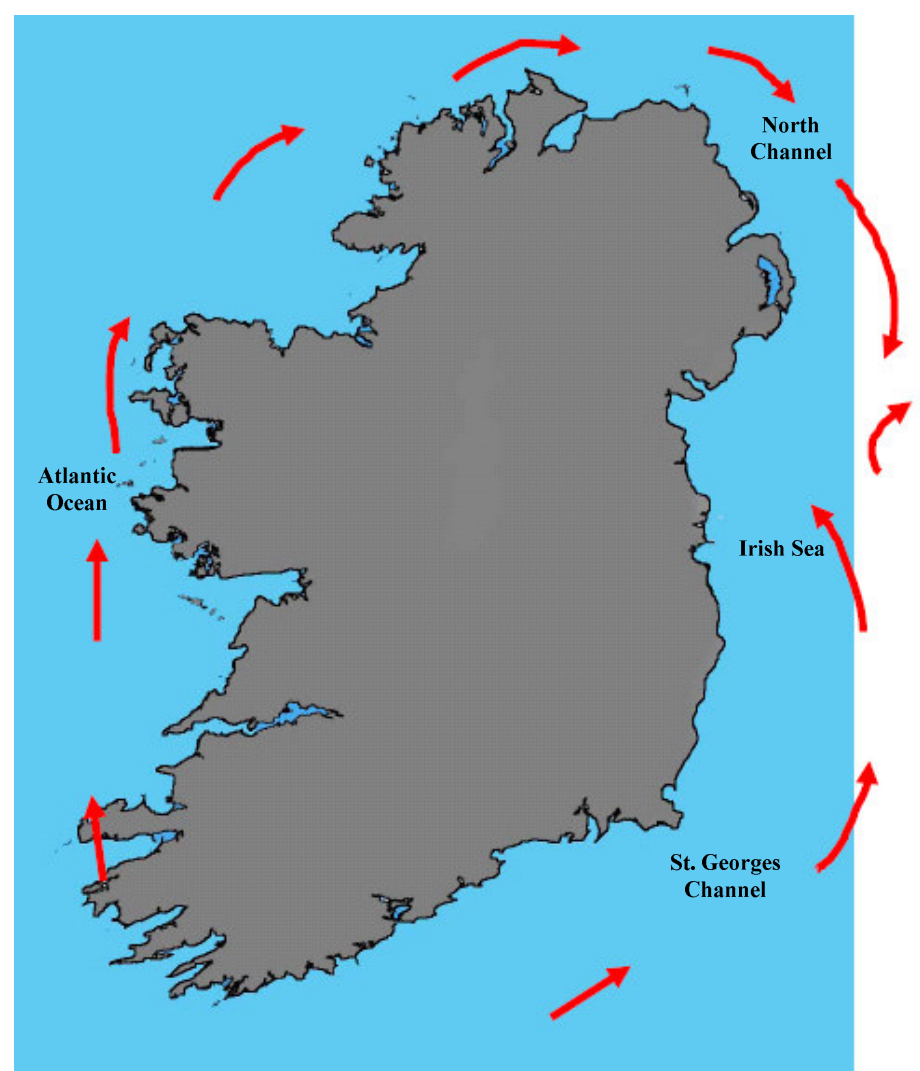

Figure 2. The oceans and the direction of flood tide around Ireland [21]

\subsection{Resource assessment}

Very little information has been published to-date regarding the exploitation of tidal current energy in Ireland. Several 2-D numerical models have been developed for simulating the tidal flow around Europe, including Ireland and the UK. However these models employed a grid spacing of between $5 \mathrm{~km}$ and $12 \mathrm{~km}$. This large grid spacing is not capable of resolving the local bathymetric features and is a source of inaccuracy. The currently adopted tidal current energy resource assessment was completed by Sustainable Energy Ireland, an organisation set up by the Irish government with the objective of promoting the development of sustainable energy technologies, and published in a report entitled Tidal and Current Energy Resources in Ireland in 2004. For this assessment the theoretical tidal current energy resource was first identified and then in turn, with the application of limitations and constraints, the technical, practical, accessible and the viable tidal current energy resources were obtained. These are discussed below.

\subsubsection{Theoretical tidal current energy resource}

The tidal current energy resource assessment was completed by firstly identifying the theoretical resource. This is basically the gross tidal energy content of a tidal current flow within a strip encircling Ireland. The landward boundary of the strip was taken at the point when the water depth reached $10 \mathrm{~m}$ and the seaward boundary was taken at the 12 nautical mile territorial limit from the coast. An engineering and environmental consultancy group called RPS Kirk McClure Morton (UK) developed a numerical model of the tidal currents around Ireland using software called Mike 21. This software, developed by the Danish Hydrographic Institute, is an engineering software package designed for the simulation of fluid flows, waves, sediments and ecology in rivers, estuaries, seas and coastal regions. In the model developed by RPS Kirk 
McClure Morton of the Irish coast, they employed a main grid spacing of $405 \mathrm{~m}$ enabling the local bathymetry and seabed conditions to be more accurately modelled than previous numerical models [22]. The grid for this numerical model also contained detailed $45 \mathrm{~m}$ and $135 \mathrm{~m}$ grid sub-models covering the most energetic sites suitable for possible development. This 2-D depth-integrated numerical model assumes uniform flow throughout the depth of the water column and is relatively accurate for sea conditions where the water column is well mixed. Figure 3 shows the predicted, peak, spring-tide velocities from the 2-D numerical model around Ireland.
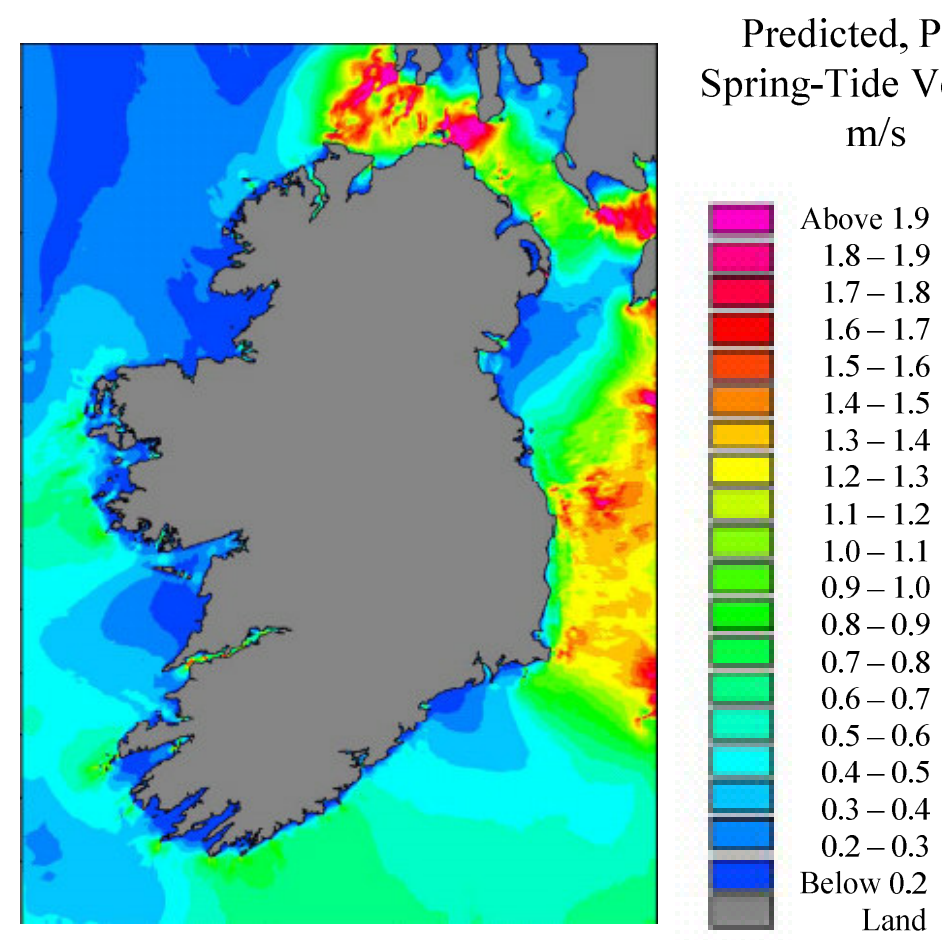

Figure 3. Predicted, peak, spring-tide velocities around Ireland predicted by RPS Kirk McClure Morton using Mike 21 software and a main grid spacing of 405 m [21]

The results shown in Figure 3 were validated along the east coast using existing data from previous measurements of tidal current velocities and along the west coast using the recorded data from the two purposely-installed Acoustic Doppler Current Profilers, the first in the Shannon Estuary and the second at the Bulls Mouth, both of which are shown in Figure 4.

The model developed for the tidal current velocities was then used to determine the mean power output, $P_{\text {mean }}$, available from a tidal flow, using Equation 1 given by Fraenkel [23]:

$$
P_{\text {mean }}=\frac{1}{2} \rho K_{s} K_{n} v^{3}{ }_{\text {peak }} \quad\left(W / m^{2}\right)
$$

where $\rho$ is the density of seawater, $K_{s}$ is the velocity availability factor $(0.424), K_{n}$ is the neap/spring factor (0.57) and $v_{\text {peak }}$ is the peak spring-tide velocity [21]. This maximum spring-tide velocity is a depth-averaged velocity and is assumed to give an accurate velocity value throughout the water column. Not all the energy can be exploited by a turbine placed in the tidal current flow however. Albert Betz (1885 1968), a German Physicist, showed that the maximum theoretical power coefficient for any turbine (assuming the rotor is frictionless and has no rotational velocity 
component in the wake) operating in a free stream flow is 0.59 . This is known as the Betz limit [24]. However, the presence of an upper and lower boundary (the surface and the seafloor) may result in an increase in the maximum theoretical power coefficient if the turbine occupies a large portion of the flow channel [21]. Once the maximum theoretical power coefficient was applied to theoretical resource the maximum cross-sectional area of the rotor based on the depth of the water column and the device spacing were introduced. The diameter of the rotor was assumed to be 0.7 times the depth of the water column. Lateral device spacing was taken as 5 diameters and upstream/downstream spacing was taken as 10-20 diameters. The theoretical tidal current energy resource for Ireland after the above constraints were applied amounted to a total of $230 \mathrm{TWh} / \mathrm{y}$.

\subsubsection{Technical tidal current energy resource}

From the theoretical tidal current energy resource the technical tidal current energy resource was assessed based primarily on the current status of existing tidal current energy technology. The technical tidal current energy resource was calculated only for sites with a tidal current peak velocity greater than $1.5 \mathrm{~m} / \mathrm{s}[25,26]$. This velocity was selected based on the current status of tidal current turbines. The tidal current turbine efficiency was assumed to be 0.39 . The technical tidal current energy resource is also limited by the current status of the deployment technology, the support structure and electrical issues, such as grid connection. The technical tidal current energy resource around Ireland was calculated as $10.46 \mathrm{TWh} / \mathrm{y}$.

\subsubsection{Practical tidal current energy resource}

The practical tidal current energy resource was determined from the technical resource by accounting for practical constraints. The practical tidal current energy resource is limited by water depth as only sites with a water depth of between 20 to 40 $\mathrm{m}$ were included in the practical tidal current energy resource assessment. Tidal current turbines cannot be installed in various areas such as shipping lanes (Tuskar Rock, Mizen Head and Fair Head), military zones (Cork Harbour, County Donegal and County Meath), restricted areas, and where submarine pipes and cables are located. Eleven sites, illustrated in Figure 4, were identified as their locations fit the water depth criteria and are not located in shipping lanes, military zones, restricted areas, and do not interfere with existing submarine pipes or cables. The practical tidal current energy resource for Ireland was then calculated based on the above limitations as $2.633 \mathrm{TWh} / \mathrm{y}$. 


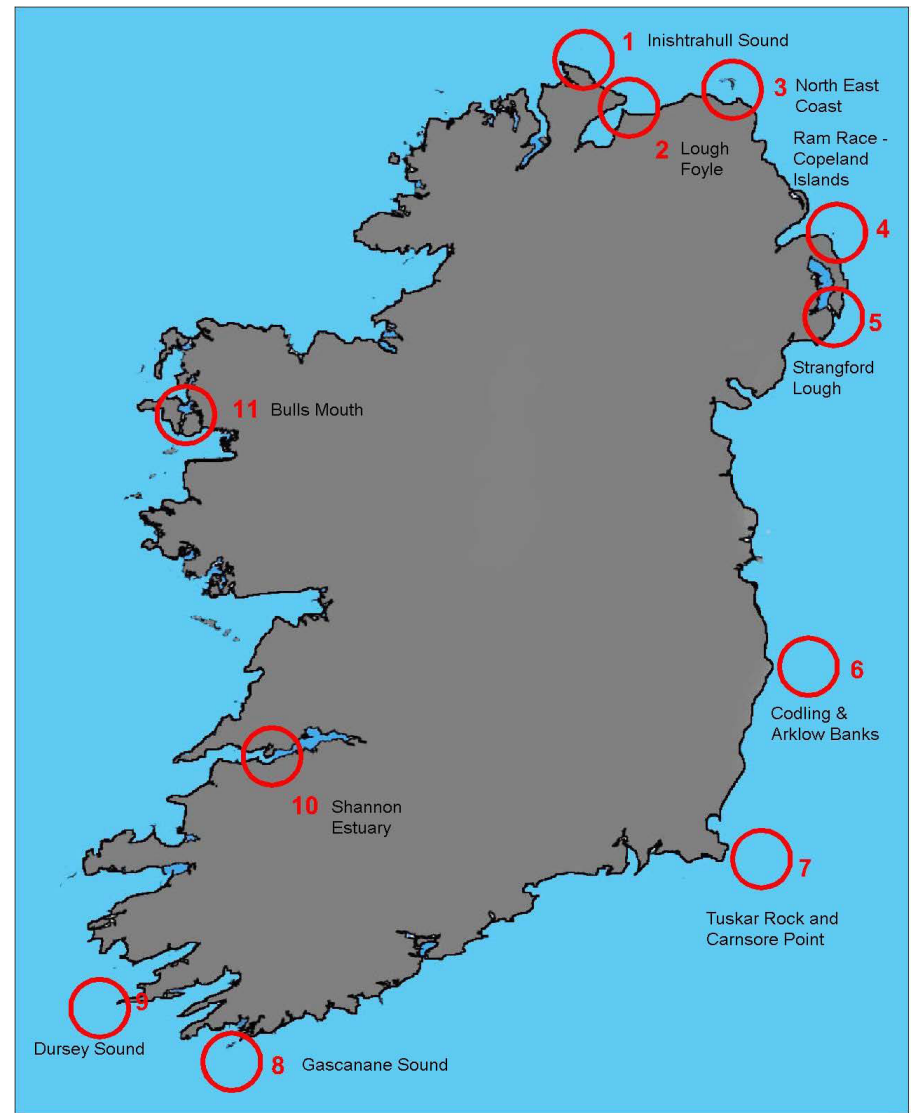

Figure 4. Location of the eleven identified practical tidal current energy sites in Ireland [21]

\subsubsection{Accessible tidal current energy resource}

The accessible resource was calculated by applying limitations to the practical tidal current energy resource. This resource assessment is basically the practical tidal current energy resource limited by man-made regulatory institutions. These limitations include environmental effects, health and safety, and planning. The effects to navigation were also considered. The requirement of various permits and permissions from the relevant authorities reduces the number of accessible tidal current energy sites. The relevant legalisation required for the development of a tidal current energy farm includes the Planning and Development Act 2000, the Foreshore Acts 1933 - 1992, EC Environmental Impact Directives 1985 and 1997, the National Monuments Act 1930 - 94, and Conservation Designations (SAC, SPA, NHA) However none of the eleven identified sites shown in Figure 3 were protected. Therefore the accessible tidal current energy resource is the same as the practical tidal current energy resource with a value of $2.633 \mathrm{TWh} / \mathrm{y}$.

\subsubsection{Viable tidal current energy resource}

The viable tidal current energy resource is the accessible tidal current energy resource constrained by commercial limitations such as costs, scale, grid connection and resource distribution of a tidal current energy farm. In order to determine the viable tidal current energy resource an economic model was used to establish the costs for each of the eleven identified sites. This economic model, developed by Marine Current Turbines Ltd. (UK), was used to determine the viable tidal current energy resource around Ireland. The model specifies the size and quantity of turbines for installation at a particular site and outputs the capital cost of the technology at each site. The viable resource is also limited by peak tidal current velocities as only sites 
with a peak tidal current velocity greater than $2 \mathrm{~m} / \mathrm{s}$ are considered economically viable. The turbine spacing was assumed to be $65 \mathrm{~m}$ apart and the position of each row of turbines was identified so to enable ships to bypass the tidal current energy farm easily. From this model the viable tidal current energy resource was estimated as $0.915 \mathrm{TWh} / \mathrm{y}$ [27]. Figure 5 illustrates the practical and viable tidal energy resource for each of the eleven locations around Ireland shown in Figure 4.

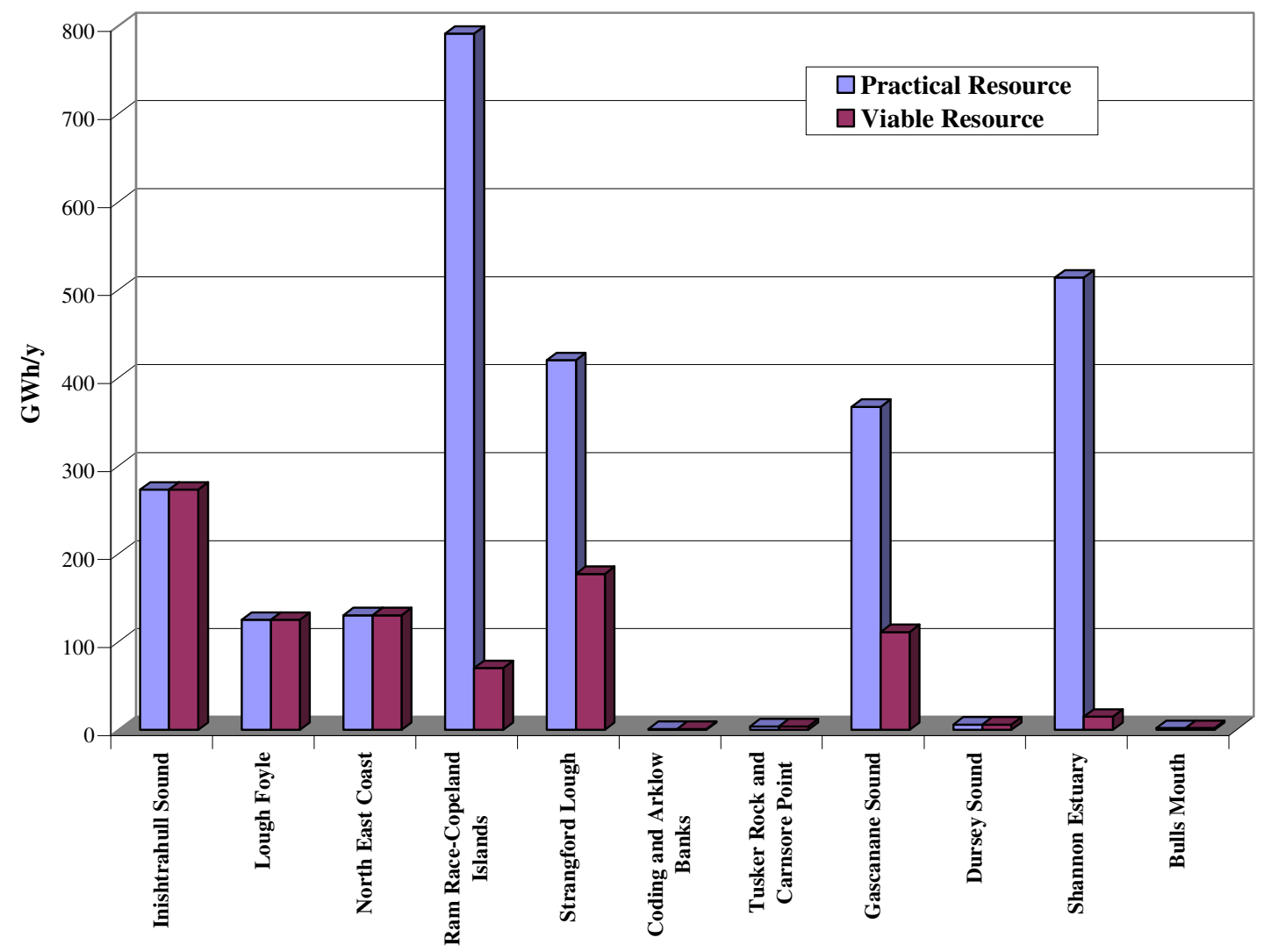

Figure 5. Practical and viable tidal current energy resource for each of the identified eleven sites around Ireland [28]

As of 2004, this resource assessment should be seen as an up-to-date indication of the size of the viable tidal current energy resource.

\subsection{Current status of tidal current turbines}

The demand for an increase in the use of renewable energy has led to developments in tidal current energy technology [29]. Tidal current turbine technology is still in its infancy however. Over the past few years several trial scale models and full scale models have been connected to a national electricity grid. These devices include SeaGen and Seaflow [30] (Marine Current Turbines Ltd., UK), Tidal Stream Turbine (Hammerfest Strom AS, Norway) and the scale model Open Centre Turbine (OpenHydro Ltd., Ireland) [31].

The recent developments in the technology have been assisted by the establishment of a dedicated marine energy test site named the European Marine Energy Centre (EMEC) in Orkney, Scotland. This marine energy test site is operational since 2005 for the purpose of testing marine energy devices. Ireland and the UK are at the forefront in the development of tidal current turbines and their deployment technology, with several projects in development[32]. There is limited information published on the development of tidal current turbines due to fact they are been developed 
primarily by private companies [33]. However the current status of these devices was reviewed in a recent paper [34].

Perhaps the best known and largest tidal current turbine is the 1.2 MW SeaGen turbine, which is being developed by Marine Current Turbines Ltd. and is currently installed in Strangford Lough (Northern Ireland). This turbine consists of a pair of twin-bladed horizontal-axis rotors, $16-\mathrm{m}$ in diameter. The turbine is currently connected to the UK national grid and is successfully operating at full power [35]. An Irish-based company called Open-Hydro Ltd. is currently testing a 6-m-diameter scale model of their device named the Open Centre Turbine at the EMEC. A 10-m-diameter device was installed in the Bay of Fundy, Nova Scotia, Canada on November $17^{\text {th }}$ 2009 [36]. Figure 6 illustrates SeaGen, Seaflow, Open Centre Turbine and Tidal Stream Turbine.
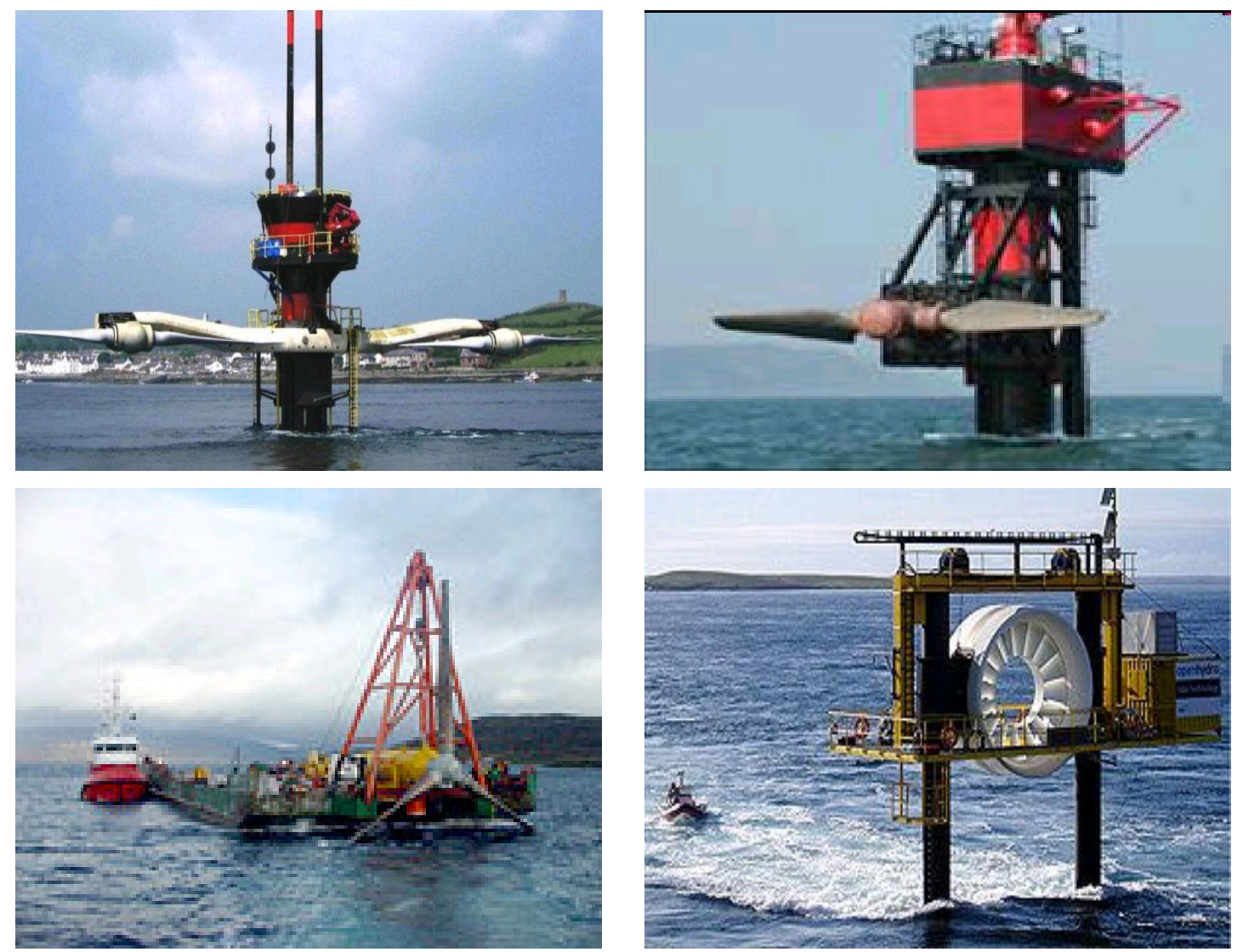

Figure 6. Clockwise from top left: SeaGen, Seaflow, Open Centre Turbine and Tidal Stream Turbine [37-39]

\subsection{Tidal current energy assessment status}

Tidal current energy extraction has the potential to play a crucial role in a sustainable energy future for Ireland. The currently accepted tidal current energy resource assessment for Ireland was published in a report in 2004. This report outlines Ireland's theoretical, technical, practical, accessible and viable tidal current energy resources. The resource assessment completed by Sustainable Energy Ireland, based on the numerical model developed by RPS Kirk McClure Morton, needs updating and only gives a rough indication of the tidal current energy resource around Ireland for the following reasons: 
1. Based on the performance of SeaGen, it has been shown that the tidal current energy resource assessment for Strangford Lough has been underestimated in the Tidal and Current Energy Resources in Ireland report in 2004. The technical director of Marine Current Turbines Ltd., Dr Peter Fraenkel, presented performance data for SeaGen at the Lisbon Ocean Power Conference in 2009 (Lisbon, Portugal, November $2^{\text {nd }}-4^{\text {th }} 2009$ ) which showed that the tidal current energy resource is more energetic than previously predicted. This indicates that the 2-D numerical model may not be sufficiently accurate. The development of a smaller more detailed grid for the 2-D numerical model may result in a more accurate theoretical tidal current energy resource assessment.

2. Without a detailed spatial map of Ireland's coastline, numerous assumptions may have been made regarding potential tidal current energy sites. This matter was identified at the Zero Carbon Society 2050 Forum in the Dublin Institute of Technology in 2009 (Dublin, Ireland, November $4^{\text {th }}$ 2009). The belief expressed at this forum was that an up-to-date tidal current energy resource assessment may identify numerous sites previously uneconomical for tidal current energy extraction resulting in the commercialisation of tidal current turbines around Ireland. An in-depth detailed spatial map of Ireland's coastline needs to be compiled in order to accurately calculate the practical and accessible tidal current energy resources.

3. The technical and practical tidal current energy resource assessments may be outdated due to the advancement in the development of tidal current turbines and their deployment technology. Currently, it is believed that it is possible to install tidal current turbines at depths greater than $40 \mathrm{~m}$ and tidal current turbines can operate at velocities less than $1.5 \mathrm{~m} / \mathrm{s}$. The recent development of the deployment technologies such as jack-up barges and other marine plant will result in an increase in the number of practical tidal current energy sites. The technical tidal current energy resource which is currently limited to a peak velocity of $1.5 \mathrm{~m} / \mathrm{s}$ will also increase with the development of tidal current turbines. For this resource assessment the peak tidal current velocity considered economically viable was 2 $\mathrm{m} / \mathrm{s}$ or greater. Information regarding the current operational status of tidal current turbines, as well as the current status of the deployment technology, is required to accurately assess the technical and practical tidal current energy resource.

An up-to-date, tidal current energy resource assessment is required to give a more detailed indication of the viable resource around Ireland. Improvements to the 2-D numerical model, the development of a detailed spatial map of Ireland, and the publishing of experimental data will assist in developing an accurate tidal current energy resource assessment for Ireland.

\section{Discussion}

Ireland depends heavily on fossil fuel imports to meet energy demand. The effect of this over reliance on fossil fuels has led to security of supply issues and the threat of climate change. Energy is an essential component for economic development in Ireland. The use of renewable energy technologies has the capability of reducing the amount of greenhouse gasses emitted, while increasing the security of energy supply.

The use of renewable energy technologies offers an indigenous non-polluting energy source. The major issue with the exploitation of renewable energy is availability. This is the case for most renewable energy technologies; however, tidal current energy is 
predictable over a large time scale, making it an excellent choice as a base load supplier.

The currently accepted tidal current energy resource assessment, completed by SEI, is based on the 2-D numerical model developed by RPS Kirk McClure Morton. This assessment was based primarily on the tidal current turbine and their deployment technology development state at that time. This has restricted the number of tidal current energy sites considered economically viable for energy extraction.

An up-to-date tidal current energy resource assessment is required based on the SeaGen tests carried out in Strangford Lough, the accuracy of Ireland's current spatial map, and the recent development of tidal current turbines and their deployment technologies. The development of a grid with more resolution may increase the accuracy of the numerical model employed in the calculation of the theoretical resource. The development of a more detailed spatial map of Ireland will enable each site to be assessed accurately. The publishing of tidal current turbine test data and information regarding deployment will also increase the accuracy of the assessment.

Political decisions and effective policies are crucial to the development of tidal current energy technology. All these issues need to be addressed to further develop the technology and make it commercially viable as an energy source.

\section{References}

1. Charlier, R.H., Sustainable co-generation from the tides:: A review. Renewable and Sustainable Energy Reviews, 2003. 7(3): p. 187-213.

2. Springer, U., The market for tradable GHG permits under the Kyoto Protocol: a survey of model studies. Energy Economics, 2003. 25(5): p. 527-551.

3. Elliott, D., Renewable energy policy in the UK: Problems and opportunities. Renewable Energy. 9(1-4): p. 1308-1311.

4. Huber, C., Ryan, L., Ó Gallachóir, B., Resch, G., Polaski, K., and Bazilian, M, Economic Modelling of Price Support Mechanisms for Renewable Energy: Case study on Ireland. Energy Policy, 2007. 35(2): p. 1172-1185.

5. Denny, E., The economics of tidal energy. Energy Policy, 2009. 37(5): p. 1914-1924.

6. Pelc, R. and R.M. Fujita, Renewable Energy from the Ocean. Marine Policy, 2002. 26(6): p. 471-479.

7. PR Cave, E.E., Tidal Stream Energy Systems for Isolated Communities, Alternative Energy Systems-Electrical Integration and Utilisation. 1984: Oxford: Pergamon Press.

8. Bahaj, A.S. and L.E. Myers, Fundamentals Applicable to the Utilisation of Marine Current Turbines for Energy Production. Renewable Energy, 2003. 28(14): p. 2205-2211.

9. Watchorn, M., T. Trapp, and A.A.M. Sayigh, Tidal Stream Renewable Offshore Power Generation (TS-Ropg), in World Renewable Energy Congress VI. 2000, Pergamon: Oxford. p. 2664-2667.

10. Marine Institute, Ocean Energy in Ireland. 2005, Department of Communications, Marine, and Natural Resources.

11. O'Rourke, F., F. Boyle, and A. Reynolds, Renewable energy resources and technologies applicable to Ireland. Renewable and Sustainable Energy Reviews, 2009. 13(8): p. 1975-1984.

12. Sustainable Energy Ireland, Energy in Ireland 1990-2006. 2007. 
13. Sustainable Energy Ireland, Energy in Ireland Key Statistics. 2008.

14. Government, I., Delivering a Sustainable Energy Future for Ireland. 2007.

15. Nairn, R., Ireland's Coastline: Exploring its Nature and Heritage. 2005:

Collins Press. 220.

16. Charlier, R.H., A "Sleeper" Awakes: Tidal Current Power. Renewable and Sustainable Energy Reviews, 2003. 7(6): p. 515-529.

17. Bahaj, A.S., Molland, A. F., Chaplin, J. R., and Batten, W. M. J., Power and Thrust Measurements of Marine Current Turbines under various Hydrodynamic Flow Conditions in a Cavitation Tunnel and a Towing Tank. Renewable Energy, 2007. 32(3): p. 407-426.

18. Boyle, G., Renewable Energy Power for a Sustainable Future. Second Edition ed. 2004: Oxford University Press.

19. Palmer, J., The Tide is Turning. The New Scientist, 2008. 200(2677): p. 35-36.

20. Lemonis, G. and J.C. Cutler, Wave and Tidal Energy Conversion, in Encyclopedia of Energy. 2004, Elsevier: New York. p. 385-396.

21. Sustainable Energy Ireland, Tidal \& Current Energy Resources in Ireland. 2004.

22. Shaw, D.M., Marine Current Tidal Energy Resource Study of Ireland. 2004.

23. P.L. Fraenkel, Power from marine currents. Proceedings of the Institution of Mechanical Engineers, Part A: Journal of Power and Energy, 2002(216 (A1),): p. pp. 1-14. .

24. Blunden, L. and A. Bahaj, Tidal energy resource assessment for tidal stream generators. Proceedings of the Institution of Mechanical Engineers, Part A: Journal of Power and Energy, 2007. 221(2): p. 137-146.

25. Bryden, I.G. and S.J. Couch, ME1--Marine Energy Extraction: Tidal Resource Analysis. Renewable Energy, 2006. 31(2): p. 133-139.

26. Bryden, I.G. and D.M. Macfarlane, The Utilisation of Short Term Energy Storage with Tidal Current Generation Systems. Energy, 2000. 25(9): p. 893907.

27. Batten, W.M.J., Bahaj, A. S., Molland, A. F., and Chaplin, J. R., Experimentally Validated Numerical Method for the Hydrodynamic Design of Horizontal Axis Tidal Turbines. Ocean Engineering, 2007. 34(7): p. 10131020 .

28. O'Rourke, F., F. Boyle, and A. Reynolds, Marine current energy devices: Current status and possible future applications in Ireland. Renewable and Sustainable Energy Reviews. 14(3): p. 1026-1036.

29. Westwood, A., Wave and Tidal - Project Review. Renewable Energy Focus, 2007. 8(4): p. 30-33.

30. Fraenkel, P.L., Marine Current Turbines: Pioneering the Development of Marine Kinetic Energy Converters. Proceedings of IMechE Part M A Journal of Power and Energy 2007(221): p. 159-69.

31. Gross, R., Technologies and Innovation for System Change in the UK: Status, Prospects and System Requirements of Some Leading Renewable Energy Options. Energy Policy, 2004. 32(17): p. 1905-1919.

32. Osalusi, E., J. Side, and R. Harris, Structure of turbulent flow in EMEC's tidal energy test site. International Communications in Heat and Mass Transfer, 2009. 36(5): p. 422-431.

33. Grabbe, M., Lalander, E.,Lundin, S. and Leijon, M., A review of the tidal current energy resource in Norway. Renewable and Sustainable Energy Reviews, 2009. 13(8): p. 1898-1909. 
34. O Rourke, F., F. Boyle, and A. Reynolds, Tidal energy update 2009. Applied Energy. 87(2): p. 398-409.

35. Marine Current Turbines Ltd. SeaGen Tidal Energy System Reaches Full Power-1.2MW. 2008 [cited; Available from:

http://www.marineturbines.com/3/news/article/17/seagen_tidal_energy_syste m_reaches_full_power_1_2mw/.

36. Open-Hydro. OpenHydro successfully deploys $1 M W$ commercial tidal turbine in the Bay of Fundy. 2009 [cited; Available from:

http://www.openhydro.com/news/OpenHydroPR-171109.pdf.

37. Marine Current Turbines Ltd. SeaGen completed: World's First MegawattScale Tidal Turbine Installed. 2008 [cited; Available from:

www.marineturbines.com.

38. OpenHydro Ltd. OpenHydro Becomes First Tidal Energy Company to Generate Electricity onto the UK National Grid. 2008 [cited; Available from: www.openHydro.com.

39. Hammerfest Strom AS. World Leading Technology Developed by Hammerfest Strom. 2007 [cited; Available from:

http://www.hammerfeststrom.com/content/view/58/86/lang,en/. 